\title{
Haberlerde Kullanılan Ölü Beden Fotoğraflarının Alımlanması
}

\section{Didem Tuncay}

Ankara Üniversitesi Sosyal Bilimler Enstitüsü

tuncay.didem@gmail.com

\section{Öz}

Bu çalıșmada, ölü bedenleri gösteren haber fotoğraflarının okurlar tarafından nasıl alımlandığı incelenmektedir. Çalıșma, Türkiye'deki ulusal gazetelerin internet sitelerinde 2015 yılında yayımlanmıș altı fotoğrafa ilișkin, farklı sosyo-demografik özelliklere sahip 10 kiși ile derinlemesine görüșmeler yapılarak gerçekleștirilmiștir. Görüșmeler; katılımcıların cinsiyetlerinin, yașlarının, eğitim düzeylerinin, mesleklerinin, kișisel deneyimlerinin, ideolojik görüșlerinin ve dini inançlarının fotoğrafların alımlanmasında farkııık yaratı̆ı̆ını göstermiștir. Bununla birlikte, katılımcılar tarafından ölü beden fotoğraflarına ilișkin çizilen etik sınırlar bulunduğu belirlenmiștir. Katılımcılar, ilk anda çok rahatsız edici buldukları fotoğraflara bakmayı ve bu fotoğraflarla ilgili kapsamlı anlam üretmeyi de reddetmișlerdir. Çalıșma, haberlerde ölü beden fotoğraflarının kullanımı konusunda yeni bir tavır geliștirilmesinin gerekli olduğu iddiasındadır.

Anahtar Kelimeler: Haber, Ölüm, Etik, Alımlama, Söylem

Makale geliș tarihi: 20.09.2016 • Makale kabul tarihi: 21.11.2016.

http://ilefdergisi.org/2017/4/1/

ilef dergisi · @ 2017 • 4(1) • bahar/spring: 59-90

DOI: 


\section{Reception of Dead Body Photographs Used in News Stories}

\section{Didem Tuncay}

Ankara University Institute of Social Sciences

tuncay.didem@gmail.com

\section{Abstract}

This study examines readers' reception of news photographs showing dead bodies. To this end, in-depth interviews were conducted with 10 people of different socio-demographic characteristics, on six photographs published on the websites of national dailies in Turkey in 2015. The interviews showed that reception of the photographs varied depending on gender, age, level of education, profession, personal experiences, ideological view and religious belief of the participants. On the other hand, it was found that there were ethical boundaries drawn by the participants, concerning photographs of dead bodies. Participants also refused to look at and attribute comprehensive meanings to the photographs which they found to be particularly disturbing at first glance. The study argues that a new approach needs to be developed regarding the use of dead body photographs in news stories.

Keywords: News, Death, Ethics, Reception, Discourse 
"Bir insan, bir hayvan veya bitkide hayatın tam ve kesin olarak sona ermesi" olarak tanımlanan ölüm, ${ }^{1}$ bütün canlıların ortak kaderidir. Martin Heidegger'e göre, sahici bir varoluş imkânı ölüm sayesinde ortaya çıar. ${ }^{2}$ Ölümün mutlak bir yok oluş mu, yoksa bir sürecin sadece parçası mı olduğunu bilebilmek mümkün olmasa da, ölüme doğru kaçınılmaz olarak ilerlediğini kabullenmek, insan için, hayat üzerine düşünme ve ona anlam katma potansiyelini barındırır.

Modern dönem öncesi kamusal nitelik taşıyan ölüm ve ölü beden, uygarlaşma süreci içinde mahrem hale gelmiştir. ${ }^{3}$ Ancak günümüzde hem bu mahremiyet hem de ölüme ve ölü bedene atfedilen kutsallık, neredeyse her gün medyada yer alan görüntülerle ihlal edilmektedir.

Guy Debord, 1967 yılında yayımlanan Gösteri Toplumu adlı kitabında, modern üretim koşullarının hüküm sürdüğü toplumların tüm yaşamının devasa bir gösteriler yığını gibi göründügünü belirtir. Doğrudan yaşanmış her şey, yerini bir temsile bırakarak uzaklaşmıştır. Yaşamdan kopmuş imgeler, ortak bir akışta birleşir. Bu akışta, yaşamın birliğinin yeniden sağlanması mümkün değildir. Kısmen göz önünde bulundurulan gerçeklik; ayrı bir sahte-dünya, salt bir seyir nesnesi olarak gözler önüne serilir. Görülen dünya, metanın 
dünyasıdır. ${ }^{4}$ Debord'un işaret ettiği gösteri sürmektedir. Gösteri toplumunda, artık ölüm ve ölü beden de medyatikleşmiş ve bir meta gibi tüketilir hale gelmiştir.

Ölü beden görüntülerinin yayımlanmasının aslında okurlar ya da izleyiciler tarafından istenildiği yönünde genel bir kabul bulunmaktadır. Görüntüler ne kadar çarpıcı olursa o kadar yüksek tiraj, izlenme oranı ya da tıklanma elde edileceği düşünülür. ${ }^{5}$ Medya kuruluşları, ölü beden görüntülerini, gerçekliğin anlaşılmasını sağlamak veya bir soruna dikkat çekmek için yayımladıklarını da zaman zaman ileri sürmektedir. ${ }^{6}$ Ancak bu görüntüler, çoğu kez hem ölen kişinin mahremiyetini ve onurunu zedelemekte hem de yakınlarının yaşadığı travmayı artırmaktadır.

Bugüne kadar, medyada ölümün ve ölü bedenlerin, özellikle savaş dönemlerinde nasıl sunulduğuna ilişkin çalışmalar yapılmıştır. Hüseyin Köse ve Bahar Balc1, Suriye'deki savaşa dair 2011-2016 yılları arasında yayımlanan fotoğraflar bağlamında, ölümün ve ölü bedenlerin görsel temsilini inceledikleri çalışmada, yoksul ve sömürgeleştirilmiş ülkelere mensup insanların ölümlerinin ve ölü bedenlerinin cömertçe sergilenebildiğine dikkat çekmişlerdir. Köse ve Balcı, aynı çalışmada, zengin ve ayrıcalıklı kesime ait ölüm imgelerinin, gözlerden olabildiğince uzak tutulduğunu belirtmişlerdir. ${ }^{7}$ Tal Morse tarafından İsrail gazeteleri üzerine yapılan bir araştırma ise, "biz" ve "ötekiler" ayrımı yapıldığını, ölü bedenlerin medyada yer alış şeklini, ölen kişinin hangi ulusa mensup olduğunun belirlediğini göstermiştir. ${ }^{8}$ Medyadaki şiddet ile ilgili daha genel bir çerçevede yürütülen çalışmalarda, çoğunlukla medya içeriklerinin etkilerine odaklanılmıştır. Bu çalışmalar, medyadaki şiddet ile toplumda gözlenen şiddet davranışları arasında neden-sonuç ilişkisinden söz edilmesinin güç olduğunu ortaya koymuştur. Öte yandan, hep olumsuz haberlerle karşılaşmanın, okurun ya da izleyicinin karamsar bakış açısını pekiştirdiği saptanmıştır. ${ }^{9}$ Medyada yer alan ölü beden görüntülerinin nasıl anlamlandırıldığı ise yeterince araştırılmamıştır. Bu çalışma; haberlerde kullanılan ölü beden fotoğraflarının, bu fotoğraflarla karşılaşan kişiler tarafindan nasıl alımlandığını, başka bir ifadeyle, nasıl kavranıp yorumlandığını inceleyerek, bu boşluğu kısmen de olsa doldurmak amacını taşımaktadır.

"Alımlama analizi" ya da "alımlama çalışmaları" geleneğinde, medya içeriklerinin okurlar ya da izleyiciler tarafından pasif bir şekilde kabul edilmediği, farklı geçmişlere sahip okurların ya da izleyicilerin aynı içerikleri farklı şekillerde kavrayıp yorumladıkları varsayılmaktadır. ${ }^{10}$ Çalışma çerçevesinde, bu varsayımdan hareketle, ulusal gazetelerin internet sitelerinde 2015 yılında 
yayımlanmış altı haber fotoğrafına ilişkin, farklı sosyo-demografik özelliklere sahip 10 kişi ile derinlemesine görüşmeler yapılmıştır. Görüşmeler sırasında, katılımcıların fotoğraflara dair ürettikleri anlamlar ve anlam üretimlerini etkileyen faktörler belirlenmeye çalışılmıştır. Katılımcıların, ölü bedenleri gösteren fotoğrafları görmeye istekli olup olmadıkları sorusuna yanıt aranmıştır. Altı fotoğraf ışığında, katılımcıların haberlerde ölü beden fotoğraflarının kullanılması konusundaki yaklaşımları ve bu yaklaşımlarını nasıl gerekçelendirdikleri de sorgulanmıştır.

Alımlamayla ilgili süreçlerin incelenmesi, medya içeriklerinin kullanımı ve etkileriyle ilgili tavır geliştirilebilmesine olanak sağlamaktadır. ${ }^{11}$ Çalışmanın sonuçlarının, bu açıdan önem taşıyacağı düşünülmektedir.

Çalışmanın kuramsal bölümünde, izleyici odaklı iletişim yaklaşımları üzerinde durulacaktır. Ancak ilk olarak, ölü beden fotoğraflarının yayımlanması hukuki açıdan ve gazetecilik etiği açısından değerlendirilecektir.

\section{Kișilik Hakkı ve Kamu Yararı}

Kişilik hakkı; kişinin yaşam, sağlık, onur, saygınlık ve isim gibi kişisel varlıklar ya da değerler üzerindeki haklarını ifade etmektedir. Kişilik hakkı; çerçeve bir kavram olarak, "kişinin, kendi hayatını başkalarıyla ne ölçüde paylaşacağını belirleme hakkı" olarak tanımlanabilecek olan mahremiyet hakkını da içerir. ${ }^{12}$ Kişinin kendi görüntüsü üzerindeki hakkı da, bir kişilik hakkıdır. Bu hak, Avrupa İnsan Hakları Mahkemesi tarafından 2012 yılında alınan bir kararda şöyle tanımlanmıştır:

Bir kişinin görüntüsü, kişinin benzersiz niteliklerini ortaya koyduğu ve onu diğer kişilerden ayırdığı için kişiliğinin temel özelliklerinden birini oluşturmaktadır. Bu nedenle, kişinin kendi görüntüsü üzerindeki hakkı kişisel gelişimin ana bileşenlerinden biridir. Bu hak, yayımlanmasını reddetme hakkı dâhil, kişinin söz konusu görüntünün kullanımını kontrol etme hakkını kapsamaktadır. ${ }^{13}$

Haber ve görüş alıp verme özgürlüğünü de kapsayan ifade özgürlüğü ${ }^{14}$ ile kişilik hakkı arasında hassas bir denge bulunur. Bu dengede, kamu yararı anahtar bir kavram olarak görülmektedir. Ancak, kamu yararı içeriği belirsiz ve esnek bir kavramdır. Ruşen Keleş, kamu yararının, dar anlamda, iyelik hakkının sınırlarının belirlenmesinde ve bu hakkın özüne yapılacak karışımlarda ölçü olarak kullanılan teknik bir terim olduğunu belirtir. Kamu yararının geniş anlamı ise, toplum yararıdır. Bu anlamda kamu yararı, siyasal ve ideolojik nitelik taşıyan ve değer yargıları içeren bir kavramdır. ${ }^{15}$ Dolayısıyla, neyin kamu yararına olduğu neyin olmadığı yoruma açıktır. 
Kişilik hakkının ölüm ile son bulup bulmadığı da, tartışmalı bir konudur. Bir görüşe göre, ölen kişinin hak ehliyeti sınırlı olarak devam eder. Bu görüş, özellikle Alman Mahkeme kararları ve doktrinince temsil edilmektedir. Türkiye ve İsviçre' de ağırlık kazanmış olan doktrinin ve İsviçre Federal Mahkeme kararlarının temsil ettiği görüşe göre ise, kişilik hakkı ölüm ile son bulur. Ancak, bir kişiliğin ihlali, sadece ilgili kişiyi değil, bu kişiyle yakın ilişkisi olan üçüncü kişileri de ilgilendirmektedir. Bu nedenle, ölen kişinin yakınları, kendi kişilik haklarının ihlal edildiğini ileri sürebilmektedirler. Bu durum, ölen kişinin kişiliğinin de dolaylı olarak korunması imkânını doğurur. ${ }^{16} \mathrm{Bu}$ imkânın ne kadar kullanılabildiğinin anlaşılması açısından, Avrupa İnsan Hakları Mahkemesi'nde görülen Hachette Filipacchi Associés- Fransa davası incelenmeye değerdir.

Korsika Valisi Claude Erignac'in 6 Şubat 1998'de Ajaccio'da öldürülmesinden 13 gün sonra, Hachette Filipacchi Associés'nin çıkardığı haftalık dergi Paris-Match'ta, Erignac'ın cinayetten kısa süre sonra çekilmiş iki sayfayı kaplayan renkli bir fotoğrafı yayımlanmıştır. Söz konusu fotoğraf, Korsika Valisi'nin, yüzü kameraya dönük olarak yerde bulunan kanlar içindeki ölü bedenini göstermektedir. Erignac'ın eşi ve çocukları, fotoğrafın kamu yararına olabilecek bilgi içermediğini, ticari kaygılarla yayımlandığını ve özel hayata saygı haklarını ihlal ettiğini ileri sürerek Fransız mahkemelerine başvurmuşlardır. Ailenin, fotoğrafın yer aldığı dergi nüshalarının toplatılması talebi reddedilmiştir. Buna karşın, Paris-Match dergisinin, fotoğrafın Erignac ailesinin rızası olmadan basıldığına ve ailenin fotoğraftan derin üzüntü duyduğuna dair bir yazı yayımlamasına, karara uymaması halinde para cezası ödemesine hükmedilmiştir. Avrupa İnsan Hakları Mahkemesi'ne başvuran Hachette Filipacchi Associés, kararın Avrupa İnsan Hakları Sözleşmesi'nin ifade ve kamu makamlarının müdahalesi olmaksızın haber alma ve verme özgürlüğüne ilişkin 10. maddesine aykırı olduğunu öne sürmüştür. Ancak Avrupa İnsan Hakları Mahkemesi, 14 Haziran 2007 tarihinde, söz konusu maddenin ihlal edilmediğine hükmetmiştir. Kararda, fotoğrafın çok yüksek tirajlı bir dergide yayımlanmasının, Erignac ailesinin cinayet sonrası yaşadığı travmayı artırdığı vurgulanmıştır. Ayrıca, Fransız mahkemelerinin kararının, başvuruda bulunan şirketin haklarını kullanmasını en az sınırlandıran yaptırım olduğu kaydedilmiştir. ${ }^{17}$

Avrupa İnsan Hakları Mahkemesi'nin bu kararına karşın, hukuki düzenlemelerin ölen kişilere ve yakınlarına yeterli düzeyde koruma sağladığını iddia etmek mümkün görünmemektir. Bu durum, çözüm arayışlarında gözleri gazetecilik etiğine çevirmektedir. 


\section{Gazetecilik Etiği}

Gazetecilik etiği, 20. yüzyılda gazetecilerin artan çeşitli baskılara karşı kendilerini ve mesleklerini korumak amaciyla uymaya söz verdikleri kurallar olarak ortaya çıkmıştır. ${ }^{18}$ Türkiye'de Basın Konseyi'nin belirlediği “Basın Meslek İlkeleri"nde, ölü beden fotoğraflarının kullanımı konusunda yol gösterici olması gereken, "Şiddet ve zorbalığı özendirici, insani değerleri incitici yayın yapmaktan kaçınılır." maddesi yer almaktadır. ${ }^{19}$

Türkiye Gazeteciler Cemiyeti'nin hazırladığı “Türkiye Gazetecilik Hak ve Sorumluluk Bildirgesi”nin ekinde bulunan “Gazetecinin Doğru Davranış Kuralları"nda ise, çocuklarla ilgili suçlarda ve cinsel saldırılarda, ölmüş bile olsalar, 18 yaşından küçüklerin isimlerinin ve fotoğraflarının yayımlanmaması gerektiği belirtilmektedir. İntihar olaylarını gösteren görüntüler ile açı kamu yararı olmadıkça cinsel saldırı mağdurlarının isimleri ve görüntüleri de yayımlanmamalıdır. "Gazetecinin Doğru Davranış Kuralları"nda, sarsıcı durumlarda, gazetecinin olaya yaklaşımının ve araştırmasının insani olması, gizliliklere uyulması ve duygu sömürüsünden kaçınılması gerektiği vurgulanmaktadır.

“Türkiye Gazetecilik Hak ve Sorumluluk Bildirgesi”nin gazetecinin temel görevleri ve ilkelerine ilişkin bölümünde ise gazetecinin şiddeti haklı gösterici, özendirici ve kışkırtan yayın yapamayacağı kaydedilmektedir. Bu bölümde, gazetecinin, "kamuya mal olmuş bir şahsiyet bile olsa, halkın haber alma, bilgilenme hakkıyla doğrudan bağlantılı olmayan hiçbir amaç için, izin verilmedikçe özel yaşamın gizliliğ̆i ilkesini ihlal edemeyeceği" belirtilmektedir. $^{20}$

Etik ilkelere uymayan gazetecilere ya da yayın organlarına meslek örgütleri tarafından "uyarma" ya da "kınama" cezaları verilebilmektedir. Daha güçlü yaptırımların bulunmaması ise, bu ilkelerin rahatlıkla ihlal edilebilmesine neden olmaktadır.

Öte yandan, kendi yayın ilkelerini açıklayan bazı medya grupları ya da kuruluşları da bulunmaktadır. Bunlardan biri olan Doğan Yayın Grubu'nun "Yazılı Basın Yayın İlkeleri" arasında, "Cesetleri yakın plan gösteren, kan ve şiddet unsurları içeren fotoğraf ve görüntüler kullanılamaz." maddesi yer almaktadır. ${ }^{21}$ Buna karşın, gruba bağlı medya kuruluşlarının bu ilkeye kimi zaman uymadıkları görülmektedir.22 


\section{İzleyici Odaklı Iletișim Yaklașımları}

İzleyici, kitle iletişim araştırmalarında her zaman merkezi konumda olmuştur. 1920'li ve 1930'lu yıllarda kitle iletişim araçlarının pasif bir kitle olarak algılanan izleyiciler üzerinde güçlü etkileri bulunduğuna inanılmıştır. Ancak yapılan araştırmalar, kitle iletişim araçlarının etkilerinin sınırlı olduğunu, izleyicilerin sanıldığı kadar pasif olmadıklarını göstermiştir. İzleyicilerin medya ve içerik tercihlerini kendi zevklerine, düşüncelerine ya da ihtiyaçlarına göre yapma eğilimde olduklarının ortaya çıkması, "Kullanımlar ve Doyumlar" yaklaşımının gelişimine zemin hazırlamıştır. ${ }^{23}$

"Kullanımlar ve Doyumlar" kuramına göre, izleyiciler aktif konumda bulunmakta, medya içeriklerini kendi ihtiyaçlarını karşılamak ve tatmin sağlamak için seçerek kullanmaktadır. 1940'lı yıllarda başlayan "Kullanımlar ve Doyumlar" araştırmalarında, "medyanın insanlara ne yaptı̆̆ı" yerine "insanların medya ile ne yaptığına" odaklanılmıştır. ${ }^{24}$ Ancak, bu yaklaşım, "her şeye gücü yeten izleyici" anlayışı nedeniyle eleştirilmiştir. "Kullanımlar ve Doyumlar" yaklaşımının, bireysel medya kullanım ve doyumlarını çevreleyen makro sosyal yapıları ve medya yapılarını ihmal ettiği belirtilmiştir. ${ }^{25}$

Kitle iletişim araştırmalarının gündemini, 1970'li yılların sonlarından itibaren, Marksist bir toplum eleştirisine dayanan "Eleştirel çalışmalar" belirlemeye başlamıştır. "Eleştirel çalışmalar" içinde yer alan "Kültürel çalışmalar" yaklaşımı, temelde anlamın inşasıyla (anlamın belirli anlatım formları içinde ve onlar aracılığıyla nasıl üretildiği ve günlük hayat pratikleri yoluyla sürekli olarak nasıl müzakere edildiği ve yapıbozuma uğratıldığıyla) ilgilenmekte$\operatorname{dir}^{26}$

“Kültürel çalışmalar"ın önde gelen isimlerinden Stuart Hall, "Kodlama/ Kodaçımı" başıklı makalesinde, iletişim sürecinin göndericiden alıcıya doğru düz bir hat olarak görülmesine karşı çıkmıştır. Hall'a göre, bu süreci birbiriyle bağlantılı, fakat kendine özgü nitelikleri bulunan -üretim, dolaşım, tüketim ve yeniden üretim- anlarının eklemlenmesi aracılı̆̆ıyla üretilen ve sürdürülen bir yapı olarak düşünmek gerekir. Hiçbir an, kendisinden sonra gelen anı garanti etmez. Mesajın ilk oluşturulduğu andan (kodlama) okunduğu ve anlaşıldığı ana (kodaçımı) kadar, iletişim sürecindeki her anın kendi varlık koşulları vardır. Hall, zincirdeki hiçbir şeyin "doğal" olmadığını vurgulamıştır. Mesajların hem oluşturulması hem de açımlanması toplumsal, ekonomik, kültürel ve ideolojik bağlamlarla bağlantılıdır. ${ }^{27}$ 
Hall, bir mesajın kodaçımının yapılabileceği üç varsayımsal konum öne sürmüştür. Bunlar hâkim konum, müzakereli konum ve karşıt konumdur. Hâkim konumda izleyici mesajı, oluşturulurken verilmek istenilen anlamıyla okumaktadır. Müzakereli konumda, mesajın bazı unsurları benimsenmekte bazıları reddedilmektedir. Karşıt konumda ise izleyici, mesaj ile verilmek istenilen tüm düz ve yan anlamları kavramakta, fakat mesajı ters yönde açımlamaktadır. ${ }^{28}$ Hall, makalesinde üç konuma işaret etmiş olsa da, daha sonra verdiği bir röportajda, müzakereli konumun tek konum olmadığını belirtmiştir. Müzakereli alanda, alt kültürler ile ilişkili bir dizi farklı konum yer almaktadir. $^{29}$

Alımlama çalışmaları; edebiyat çalışmaları, "Kullanımlar ve Doyumlar" ve "Kültürel çalışmalar" geleneklerinin kesişme noktasında bulunmaktadır. Alımlama çalışmaları; edebiyat çalışmalarından, okurların, edebi eserlere kendi deneyimleri doğrultusunda anlam verdikleri düşüncesini almıştır. "Kullanımlar ve Doyumlar" yaklaşımı, mesaj karşısında çeşitli yanıtlar geliştiren aktif izleyici modelini sağlamıştır. "Kültürel çalışmalar" ise alımlama çalışmalarına, kodlanmış bir metin bulunduğu ve bu metnin kodaçımının farklı şekillerde yapılabileceği düşüncesi ile katkıda bulunmuştur. ${ }^{30}$ Alımlama kuramına göre, farklı geçmişlere sahip izleyicilerin medya içeriğine ilişkin anlam üretimlerinde kendi konumları belirleyicidir. ${ }^{31}$

David Morley'nin 1980 yılında Stuart Hall'un "Kodlama/Kodaçımı" modelini temel alarak yaptığı araştırma, alımlama çalışmalarının önemli örneklerinden biridir. Morley, BBC televizyonunda yayımlanan "Nationwide" adlı programın kodaçımının belirli izleyici gruplarına göre nasıl farklılaştığını tespit etmeye çalışmıştır. Programın bir bölümünü 26 farklı izleyici grubuna izleten Morley, toplumsal konumun katılımcıların okumaları ile doğrudan bağlantılandırılamayacağı sonucuna ulaşmıştır. Morley, anlamın, okuyucunun metne yansıttığ1 söylemlere (bilgi, önyargılar, direnişler vb.) göre farklılaştığ1nı saptamıştır. ${ }^{32}$ Tamar Liebes ve Elihu Katz, "Dallas" dizisinin alımlanmasına ilişkin çalışmalarında, farklı etnik gruplardan izleyicilerin dizinin kodaçımını farklı şekillerde yaptıklarını tespit etmişlerdir. ${ }^{33}$ Danimarka televizyonunda 1985 yılında yayımlanan haber programı "Tv-Avisen"in alımlanmasına yönelik bir çalışma ise, izleyicilerin eğitim düzeylerinin, cinsiyetlerinin ve yaşlarının haberlerin alımlanmasında farklılık yarattığını göstermiştir. ${ }^{34}$ Feminist bazı araştırmacılar tarafından yapılan çalışmalar da, alımlamada cinsiyetler arasındaki farklılıkları ortaya çıkarmıştır. ${ }^{35}$ 


\section{Çalıșmanın Yöntemi}

Alımlama çalışmaları, grup görüşmeleri ya da bireysel görüşmeler ile yapılabilmektedir. Ancak, grup görüşmelerinde bazı katılımcılar baskın olmakta, diğerleri fikirlerini ifade etmekte kısıtlanmaktadır. ${ }^{36}$ Bu nedenle, çalışmada bireysel görüşmeler tercih edilmiştir. Çalışma çerçevesinde, 10 kişi ile derinlemesine görüşmeler yapılmıştır. Katılımcı sayısının 10 ile sınırlı tutulmasının nedeni; istatistiki veri elde etmenin değil, özel alımlama biçimlerine odaklanmanın istenilmiş olmasıdır. Fotoğrafların alımlanma biçimi ile cinsiyet, yaş ve eğitim düzeyi gibi değişkenler arasındaki ilişkinin incelenebilmesi amacıyla katılımcılar belirlenirken, farklı sosyo-demografik özelliklere sahip olmalarına özen gösterilmiştir. Katılımcılar, 18-74 yaş aralığında bulunan beş kadın ve beş erkektir. Eğitim düzeyleri ilkokuldan lisansüstü eğitime kadar farklılık gösteren katılımcılar arasında iki akademisyen, iki işçi, iki öğrenci, bir doktor, bir gazeteci, bir mimar ve bir ev kadını bulunmaktadır. Katılımcılara, kendilerini daha rahat ifade edebilecekleri düşüncesiyle, isimlerinin gizli tutulacağı bilgisi verilmiştir. Çalışmada, katılımcıların ad ve soyadlarının sadece baş harfleri yer almaktadir.

Çalışmada kullanılan altı fotoğraf, ulusal gazetelerin internet sitelerinde 2015 yılında yayımlanan, doğrudan kendileri ya da temsil ettikleri olaylar gündem oluşturmuş fotoğraflar arasından seçilmiştir. İlk fotoğraf, "Aylan bebek" olarak tanınan Suriyeli Alan Kurdi'nin fotoğrafıdır. Bu fotoğraf, hem ikon haline geldiği hem de yayımlanması etik bir tartışma yarattığı için seçilmiştir. İkinci ve üçüncü fotoğraflar, iki terör saldırısına ilişkindir. Fotoğraflardan biri yakın plan, diğeri genel plan çekilmiştir. Bu seçimle, fotoğrafların alımlanma biçimi ile ölü bedenlerin farklı planlarda gösterilmesi arasında ilişki bulunup bulunmadığı incelenmek istenmiştir. Dördüncü fotoğraf, kan görüntüsünün buzlanmasının anlam üretiminde farklılık yaratıp yaratmadığını belirleyebilmek düşüncesi ile kan unsuru buzlanmış olduğu için seçilmiştir. Beşinci fotoğraf, Şırnak'ta güvenlik güçleri ile PKK'nın gençlik yapılanması YDG-H üyeleri arasında yaşanan çatışmada öldükten sonra ölü bedeni zırhlı bir polis aracının arkasına bağlanarak sürüklenen Hacı Lokman Birlik' in fotoğrafıdır. Bu fotoğrafın seçilmesinin nedeni, fotoğrafa ve ölü bedene yapılan muameleye ilişkin anlam üretiminin, ölen kişinin kim olduğuna göre farklılık gösterip göstermediğini tespit edebilmektedir. Altıncı fotoğrafın seçiminde ise, ölen kişinin yüzü açık şekilde bir tabutun içinde olması rol oynamıştır.

Görüşmelerde, yarı yapılandırılmış görüşme tekniği uygulanmıştır. Katılımcılara önceden hazırlanmış sorular sorulmuş, gerek görüldüğünde ila- 
ve sorular yöneltilmiştir. Katılımcılara fotoğraflar tek tek gösterilmiştir. Her fotoğraf için, katılımcılardan, fotoğrafta ne gördüklerini ve fotoğrafın kendilerinde nasıl bir duygu ve düşünce uyandırdığını serbest biçimde anlatmaları istenmiştir. Katılımcılara, fotoğrafta kendilerini rahatsız eden bir nokta bulunup bulunmadığı sorulmuş; kendileri değinmemişler ise, ölen kişinin yüzünün ya da kan unsurunun görünmesini nasıl anlamlandırdıklarına ilişkin ilave sorular yöneltilmiştir. Katılımcılara, altı fotoğraf ışığında, ölü beden fotoğraflarının haberlerde kullanımı konusundaki yaklaşımlarını ve bu yaklaşımlarını nasıl gerekçelendirdiklerini anlamaya yönelik sorular da yöneltilmiştir. Görüşmeler, 22 Aralık 2015- 27 Ocak 2016 tarihleri arasında gerçekleştirilmiştir.

\section{Fotoğraflar ve Bulgular}

\section{Fotoğraf}

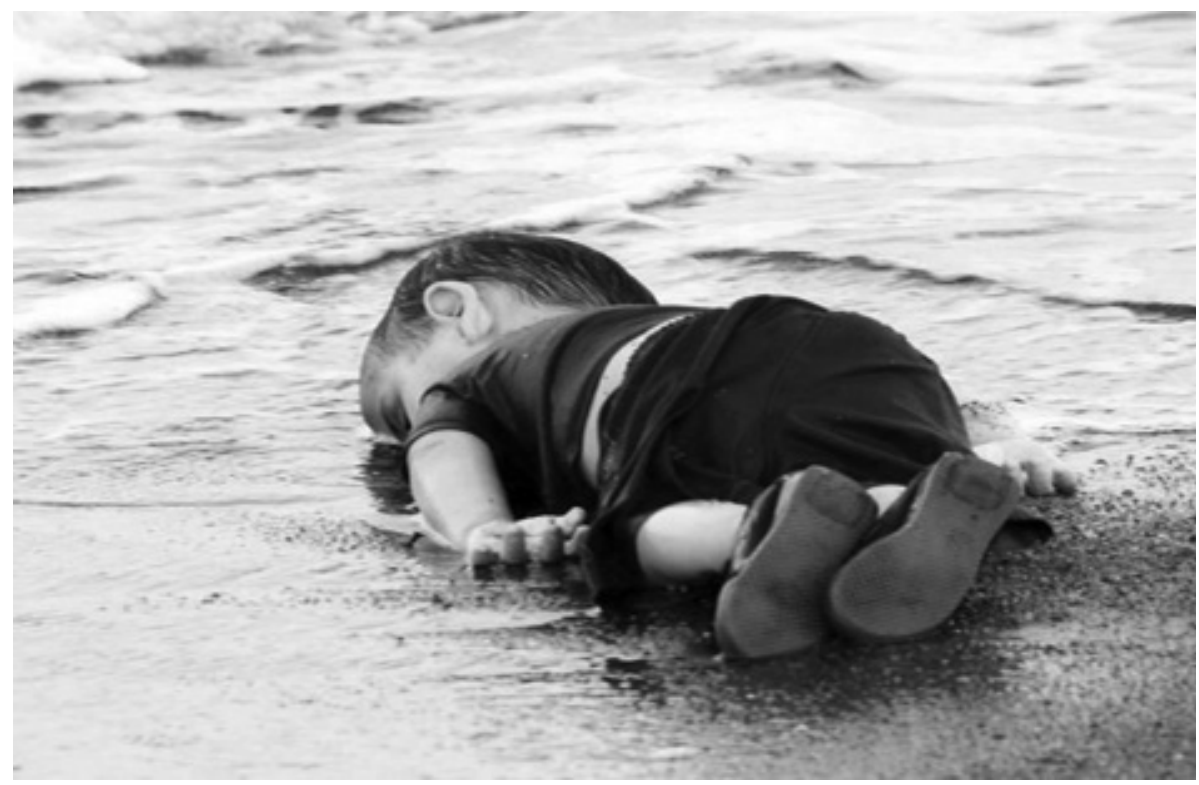

http://www.hurriyet.com.tr/bodrumdaki-faciada-isyan-ettiren-gercek-29976365

(Erișim tarihi: 1 Kasım 2015)

Katılımcılara ilk olarak, Türkiye'den Yunanistan'a geçmeye çalışan ailesiyle birlikte içinde bulunduğu botun batması üzerine hayatını kaybeden üç yaşındaki Alan Kurdi'nin, Doğan Haber Ajansı muhabiri Nilüfer Demir tarafından çekilen ve savaş nedeniyle ülkelerinden ayrılan Suriyelilerin yaşadıkları dramın simgesi haline gelen bir fotoğrafı gösterilmiştir. Katılımcıların 
tümü, fotoğrafı daha önce gördüklerini söylemişlerdir. Fotoğrafın alımlanmasında, kadın katılımcılar ve erkek katılımcılar arasında farklılıklar olduğu gözlenmiştir. Kullandıkları ifadeler, kadın katılımcıların, erkek katılımcılara göre, kendilerini Alan Kurdi ve yakınlarıyla daha fazla özdeşleştirdiklerini göstermiştir. Kadın katılımcılar fotoğrafı anlamlandırırken ne hissettiklerine odaklanmışlar; erkek katılımcılar ise, daha çok ideolojik görüşleri doğrultusunda anlam üretmişlerdir. Erkek katılımcılardan eğitim seviyesi daha yüksek olanlar, fotoğrafın çağırdığı hissiyat alanına girmemiş̧lerdir.

Fotoğrafın yayımlanması konusunda da, farklı görüşler ifade edilmiştir. Kadın katılımcıların büyük bölümü, bir çocuğun ölü bedeninin bu şekilde gösterilmesinden rahatsızlık duyduklarını söylemiştir. Erkek katılımcılardan eğitim seviyesi daha yüksek olanlar ise, fotoğrafın yayımlanmasının olumlu sonuçlar da doğurduğu yönündeki görüşlerini dile getirmişlerdir.

Kadın katılımcılardan O.T. hiçbir zaman ölü görmek istemediğini söylemiştir.

Fotoğrafta küçük bir erkek çocuğun cansız bedenini görüyorum ve bu beni çok kötü yapıyor... Dalgalar onu sürüklemiş. Kim bilir denizin içinde dalgalarla ne kadar boğuştu ve can verdi; insan aklına bile getirmek istemiyor. Ölü beden bende çok kötü hisler uyandırıyor. Hiçbir zaman ölüye bakmak istemem, ölü görmek istemem.

B.Y. fotoğraftaki çocuğun öldüğünü kabullenmekte zorlandığını aktarmiştır.

Bana çok kötü hissettiriyor. Bir çocuk ölmüş. Tek başına. Halbuki yanında ailesinin, özellikle annesinin olması gerekirdi. Sanki ölmüş gibi değil de uykuya dalmış gibi; keşke öyle olsaydı.

Fotoğraf, M.C'ye kendi çocuklarını hatırlatmıştır.

Bu fotoğraf beni çok rahatsız ediyor. Anneyim aslında ama öncelikle bir insan olarak çok duygulanıyorum. Çok üzücü. Hiçbir şey diyemiyorum.

G.K. fotoğrafta yalnız bir çocuk gördüğünü ve kendini çaresiz hissettiğini ifade etmiştir.

Fotoğrafta yalnız bir çocuk görüyorum; çünkü yalnızlık duygusunu biliyorum. İçimi acıtıyor. Şimdi mesela orada olsam, kucağıma alsam, sarılsam kalbi tekrar atmaya başlar mı diye düşünüyorum. Çok kötü hissediyorum kendimi. Hiçbir şey yapamıyor olduğunu hissetmek çok acı. 
G.K. fotoğrafın yayımlanmasından rahatsızlık duyduğunu belirtmiştir.

Çocuğun bedeninin bu şekilde gösterilmesinin çok kötü olduğunu düşünüyorum. Şu anda, bakarak, sanki bedenine haksızlık ediyormuşum, onu taciz ediyormuşum gibi geliyor. Çok kötü hissediyorum kendimi. Sanki suça ortak olmak gibi geliyor.

Kadın katılımcılardan E.K. de, acizlik ve suçluluk hissettiğini söylemiştir.

Acizlik ve suçluluk duygusu; bana düşündürdüğü bu. Fotoğrafı çekilebiliyor ama başka bir şey yapılamıyor.

Erkek katılımcılar, daha önce belirtildiği gibi, kadın katılımcılardan farklı anlamlar üretmişlerdir. Erkek katılımcılar tarafından üretilen anlamlar, eğitim seviyelerine göre, kendi içinde de farklılaşmıştır. İlkokul mezunu U.D. fotoğrafın çekilmesini eleştirmiştir.

Üzülüyorum. Küçücük bir çocuk, çaresiz. Bu yaşta ne yapabilir, kendini nasıl koruyabilir ki? Fakat, bu fotoğrafa baktığım zaman daha çok düşündüğüm şey, bu çocuğun böyle bir fotoğrafını çekecekleri yere belki gidip ölü olup olmadığına bakabilirlerdi. Belki çocuk daha ölmemişti, belki yardımcı olabilme şansları vardı. Onun fotoğrafını çekmek bence ayıp.

Kendi yakınları ile Alan Kurdi'yi özdeşleştiren lise mezunu A.Ö., ideolojik görüşleri doğrultusunda da anlam üretmiş ve dünyadaki bütün yönetimlerin kaldırılması gerektiğini söylemiştir.

Hanım ağlamıştı bu çocuğu gördüğünde. Bizim de yeğenlerimiz var, torunlar var. İnsanlığın ayıbı bu görüntü. İnsanlar bir çıkış arıyorlar, çıkış yolunda telef oluyorlar. O çocukların hiçbir günahı yok. Bütün günah başta, yukarıda. Bunların sebebi onlar. Benim bir düşüncem vardır; bütün dünyadaki yönetimleri kaldırsınlar, halklar arasında kavga, gürültü olmaz.

Doktora derecesine sahip olan H.S. fotoğrafın çok ses getirdiğini ve etki yarattığını, bu nedenle yayımlanmasının iyi olduğunu ifade etmiştir.

Burada hem bir çaresizlik var, hüzün var; aynı zamanda hakikaten bir edilgenlik. Benim şahsi görüşüm, bu fotoğraf iyi ki yayınlandı. Çok da ses getirdi, çok etkisi oldu. Bir şeyin ne kadar kötü bir şey olduğunun anlaşılması, onun bir daha yaşanmaması için sunulması gerekiyor. Belki hakikaten kötüye ait birtakım şeyler var ki medyada hiç yer almaması iyi olabilir; ama bu, şekil itibarıyla kötü bir şey değil. 
Doktora derecesi bulunan B.Ü. de fotoğrafın yayımlanma amacını sorgulamış ve "duygu siyaseti" yapıldı̆̆ını söylemiştir. Bir akademisyen olan B.Ü.'nün anlam üretiminde, mesleğinin de etkili olduğu gözlenmiştir.

Bu tip fotoğrafları gördügümde bir tür ikiyüzlülük aklıma geliyor; ama sadece devletlerin veya halkların ikiyüzlülüğü değil, kendimin veya kendim gibi yaşayan insanların da ikiyüzlülüğüne ilişkin bir şey. Çünkü bu fotoğraflar sonuçta insanların vicdanlarına yönelik bir sergileme. Yayınlanma amacı, yayılma amacı insanların vicdanının rahatsız olması bir şekilde. Bunu sivil toplum da yapabiliyor, devletler de yapabiliyor. Bazıları bu fotoğrafı yayarak Suriye ve göçmenler meselesine ilgi çekmeye çalışıyor. Devletler mesela bunu manipüle etmeye çalışıyor. Bu fotoğraftan sonra Türkiye- Avrupa Birliği ilişkileri değişti, Merkel'in tavrı değişti, Avrupa'da müthiş bir değişim oldu. Yani bir duygu siyaseti görüyorum ben burada; iyi ve kötü anlamda.

B.Ü. sosyal medyada bir "duyguculuk yarışması" yaşandığını ve bunu ahlaki bulmadığını da belirtmiştir.

Benim kızdığım şey, bir tür santimantalizm yani duyguculuk... Bir şekilde kendinin ne kadar üzüldüğünü göstererek ve başkalarının nasıl bu kadar üzülmediğini göstererek bir tür üstünlük çıkartmak... Bir duyguculuk yarışması oluyor. İnsanlar bunu kendileri de fark etmeden yapıyorlar. Bunu doğrudan yapmiyorsun ama mesela bir fotoğrafı görüp "Utanıyorum küçük çocuk. Beni affet.” yazıyorsun. Böyle bir mesaj çok fazla oluyor. "Utanıyorum küçük çocuk. Beni affet." demek ve bunu paylaşmak bence çok ahlaki değil. Çocuğun cesedi üzerinden kendine duygusal bir şey yaratmaya çalışıyorsun ve bunu insanlara gösteriyorsun.

Katılımcılara, fotoğrafı gördükten sonra, Türkiye'ye sığınan Suriyeliler için herhangi bir şey yapma ihtiyacı hissedip hissetmedikleri sorulmuştur. Bu soruya, katılımcıların yarısı "Evet", diğer yarısı "Hayır" yanıtını vermiştir. "Evet" yanıtını veren katılımcılar, hissettikleri ihtiyaca rağmen hiçbir şey yapmayacaklarını, çünkü ne yapabileceklerini bilmediklerini ya da yapabilecekler bir şey bulunduğunu düşünmediklerini söylemişlerdir. Soruya "Hayır" yanıtını veren katılımcılardan U.D., değişim yaratabileceğine inanmadığını belirtmiştir.

Harekete geçme ihtiyacı çok fazla duymuyorum açıkçası. Yapabileceğim bir şey olduğunu düşünüp harekete geçsem de, en fazla harekete geçtiğimle kalırım yani. 
B.Ü. kendini Suriyelilere karşı sorumlu hissetmediğini ifade etmiştir.

Bu fotoğrafı gördükten sonra, bu konuda bir şeyler yapayım düşüncesi aklıma gelmiyor. Bu, benim duygusal dünyamın, politik dünyamın dışında kalıyor. Tabii üzülüyorsun ama benim sorumlu hissettiğim başka alanlar, insanlar var.

Katılımcilardan sadece H.S., Suriyeliler konusunda elinden geleni yapmaya çalıştığını söylemiş, ancak bunun fotoğraf nedeniyle olmadığını vurgulamıştır.

Suriyeliler konusunda elimden geleni yapmaya çalışıyorum. O konuda bir hassasiyetim var zaten. $\mathrm{Bu}$, fotoğrafla uyanmış bir durum değil; fotoğraftan önce de olan bir durum.

\section{Fotoğraf}

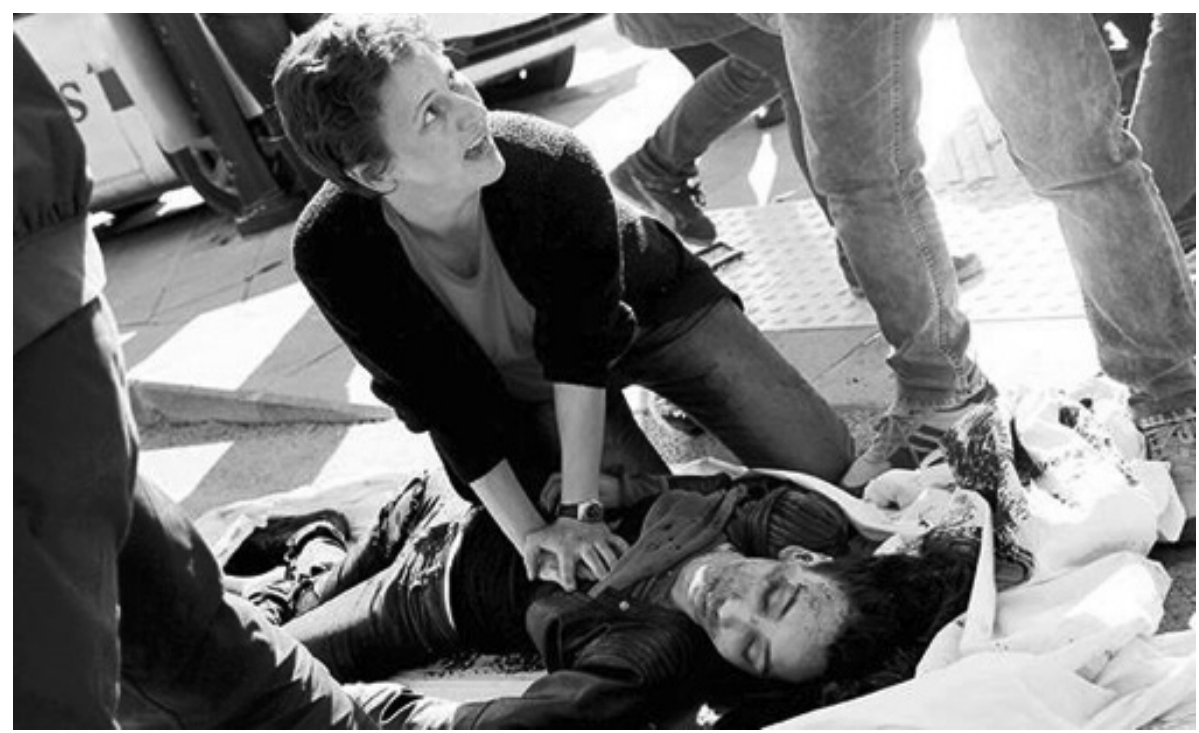

http://www.gazetevatan.com/3-saniye-arayla-2-canli-bomba--872639-gundem/

(Erișim tarihi: 1 Kasım 2015)

Katılımcılara ikinci olarak, "Emek, Barış, Demokrasi Mitingi” öncesi Ankara Garı'nın önünde düzenlenen ve 100'den fazla kişinin hayatını kaybetmesi, yüzlerce kişinin yaralanması ile sonuçlanan terör saldırısının ardından çekilmiş bir fotoğraf gösterilmiştir. Katılımcıların, fotoğrafın Ankara'daki saldırıya dair olduğunu bilip bilmemelerinin anlam üretimlerini etkilediği görülmüştür. Fotoğrafın nerede çekildiğini bilen katılımcılar, daha çok ideolojik görüşleri doğrultusunda anlam üretmişlerdir. Bu katılımcılardan biri, B.Ü.'dür. 
Bu fotoğraf, benim içimde büyük bir öfke yaratıyor. Çünkü benim gibi yaşayan, benim gibi düşünen insanlara yönelik bir saldırı bu. Benim gibi insanları öldürmüşler. Ben de ölebilirdim, benim yakınlarım da ölebilirdi... Göz göre göre katlettiriliyorlar. Bunun bir şekilde, dolaylı da olsa devletle alakalı olduğunu düşünüyorum... Sonuçta bu ülkenin solcuları her zaman öldürülüyor ve hiç kimse hiçbir şekilde hesap vermiyor, sorgulamıyor. Dediğim gibi, daha çok benim hayat tarzıma, dünya görüşüme yönelik, çok açık bir çoğunluktan, İslam'dan gelen ve aynı zamanda devletten gelen bir saldırı olarak görüyorum.

G.K. benzer bir saldırının etrafta her an olabileceğini düşündüğünü ve korku hissettiğini aktarmıştır.

Burada yardım etmeye çalışan biri var. Yüzündeki ifadeye bakıyorum. Çok canımı yaktı benim bu fotoğraf... Düşündüğüm şey, bunun etrafımızda her an olabileceği. Hissetiğim şey ise, korku.

Fotoğrafın Ankara'daki saldırının ardından çekildiğini bilmeyen katılımcıların anlam üretimlerinde ise, meslekleri ya da kişisel deneyimleri devreye girmiştir. Bir doktor olan H.S., kaçınılmaz olarak, yapılan müdahalenin doğru olup olmadığını, yerde yatan kişinin nefes yolunun nasıl olduğunu düşündüğünü söylemiştir.

Doktor gözüyle baktı̆̆ın zaman iş biraz farklı oluyor. Yani bir çaresizlik var, bir şeyler yapmaya çalışıyor ama bence zaten bu biraz zor bir durumda. Ben daha çok teknik olarak bakıyorum. Bu işi doğru mu yapıyor, nefes yolu nasıl, kaçınılmaz olarak o aklıma geliyor... Dolayısıyla hayatta kalma ve hayatta bırakma mücadelesi gibi yorumlarım bunu.

O.T.'nin anlam üretiminde ise, kendi deneyimi belirleyici olmuştur.

$\mathrm{Bu}$, anladığım kadarıyla kalp krizi geçiren bir insan, ona masaj yapıyorlar. Bunu hiç görmek istemezdim, çünkü eşim de kalp krizinden ölmüştü. Kalp krizi geçirdi, ona da masaj yaptılar, sonra makineye bağladılar. Birkaç kere tekrar kalp krizi geçirdi ve en sonunda hayatını kaybetti.

Katılımcıların büyük bölümü, fotoğrafta gördükleri kanın kendilerini rahatsız ettiğini aktarmışlardır. Bazı katılımcılar ise, rahatsız olmadıklarını çünkü kan görmeye "alıştıklarını" söylemişlerdir. Bu katılımcılardan biri, A.Ö.'dür.

Bunlar televizyonlarda hemen hemen her gün gördüğümüz şeyler. Beyin olarak alıştık artık, kana alıştık. İnternet çağında yaşıyoruz. İnternette buzlama falan yok, açık gösteriyorlar, herşeyi görüyorsun. Normal bir şeymiş gibi bakıyorsun. 
B.Ü.'nün olaya ilişkin görüntülerin kendisinde yarattı̆̆ı ilk etkinin, aynı görüntülerle tekrar karşılaştığında kaybolduğunu ifade etmiş olması da kayda değerdir.

Olay günlerinde hem fotoğraflar hem de bazı televizyon görüntüleri, panik halindeki insanların bir şeyler yapma çabası çok etkiledi beni, ama şu an aynı duyguyu yaratmıor... Ölen kişiyle ilgili duygular büyük ölçüde benden gitmiş durumda, kaybolmuş durumda. Daha ziyade ölenlere değil de öldürenlere karşı duygu aktif olarak devam ediyor... Çünkü herhalde alıştık. İnsan bir şekilde bir tür savunma mekanizmasıyla değerlendiriyor, alışıyor.

\section{Fotoğraf}

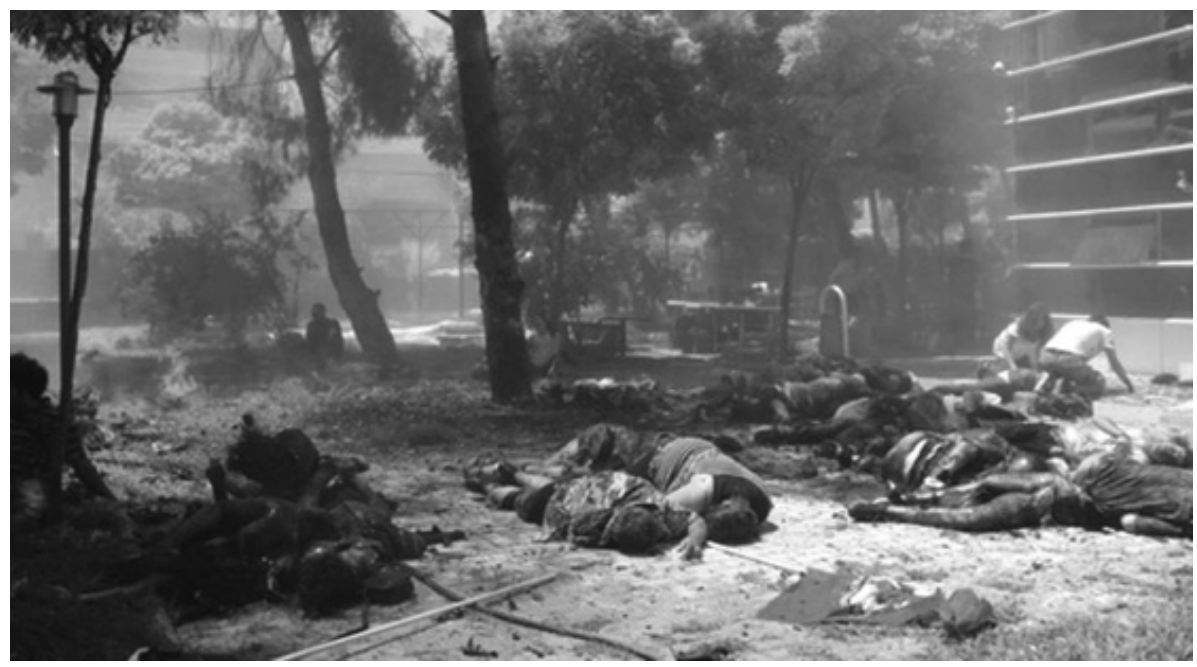

http://www.turkiyegazetesi.com.tr/yasam/290511.aspx

(Erișim tarihi: 1 Kasım 2015)

Katılımcılara üçüncü olarak, Şanlıurfa`nın Suruç ilçesinde düzenlenen bombalı saldırıdan sonra çekilmiş bir fotoğraf gösterilmiştir. Bu fotoğraf, ikinci fotoğrafın aksine, saldırının gerçekleştiği alanı genel plan göstermektedir. Katılımcıların yarıya yakını fotoğrafı "çok korkunç" ya da "rahatsız edici" bulduğunu söyledikten sonra, fotoğrafa daha fazla bakmak istemediğini belirtmiş ve bunun ötesinde anlam üretmeyi reddetmiştir. Diğerlerinden daha ileri yaşlarda olan bu katılımcılar arasında, üç kadın ve bir erkek bulunmaktadir.

Diğer grupta yer alan katılımcılardan U.D., kendini saldırıda ölenler ve aileleri ile özdeşleştirmiştir. 
Bunu bir insan yapamaz. Bu insanların hayatı, arkalarında bırakacakları aileleri var. Çok kötü bir durum. Burada ölenlerin aileleri şu anda nasıldır, nerededir düşünemiyorum.

H.S.'nin fotoğrafa ilişkin anlam üretiminde yine doktorluk mesleği etkili olmuştur. Bombalı saldırıların "ölüm şekli” haline geldiğini söyleyen H.S., benzer görüntülerle çok karşılaştığı için duyarsızlaştığını ifade etmiştir.

Doygunluk diye bir şey var. Yani reseptörlerinizle bir takım şeyleri algıladıkça, bir takım şeyler yaşadıkça ona adapte oluyorsunuz, o negatifler üzerinden duyarsızlaşıyorsunuz. Bu da öyle bir fotoğraf. Dünyanın ya da ülkenin çok daha farklı bir döneminde bu daha farklı bir anlama karşılık gelebilirdi ama bütün bunların ötesinde hakikaten öyküyü bilmek esasında buna anlam veren, fotoğrafın bizatihi kendisi değil. Yani Allah göstermesin şuradaki bir kişinin tanıdığınız biri olması ne kadar farklı hale getirir ya da bu insanların hayat öyküsünü bildiğiniz zaman sizi çok farklı etkileyebilir ya da buna maruz kalmalarının gerekçeleri sizi etkileyebilir; ama şu ya da bu şekilde artık maalesef dünyanın bir gerçeği bu oldu, ölüm şekli oldu.

Fotoğrafın çekildiği yerin ne kadar uzakta olduğunun da anlam üretimini etkileyebildiği saptanmıştır. B.Ü. Ankara Garı'nın önündeki saldırıya ilişkin fotoğrafta olduğu gibi öfke hissettiğini, ancak hislerinin diğer fotoğraftaki kadar yoğun olmadığını söylemiştir. Bunun nedenini açıklarken, “Uzakta bir yerdi. O coğrafyada zaten oluyor." demiştir.

Ankara'dakine çok benzer bir şey hissettim. Ankara' daki daha yakındı, bu biraz daha uzak. Sosyalist gençler, Kürdistan bağlantısı var burada... Korkunç bir şey. Ortalarında patlamış ama uzakta bir yerdi. O coğrafyada zaten oluyor. IŞİD var, devlet var, PKK var ama buradaki, Ankara'daki, çok daha yakındı, çok daha yoğun hissettim.

B.Y. bu tür fotoğrafların yayımlanmasını eleştirmiş ve ölümlere alışılmaması gerektiğini belirtmiştir.

Bir şeyi protesto etmeye, bir hak arayışında bulunmaya gitmişler. Etrafta hareket eden insanları görüyorum, hemen müdahale ediyorlar ve ölü insanlar, herhalde yanmış, vücutları üst üste dizilmiş... Bu tarz görüntüler bize o kadar çok sunuluyor ki, zaten istenen de bizim bunlara alışmamız, insan ölümlerine alışmamız ama ben şöyle düşünüyorum, her fotoğrafı gördügüumüzde, üst üste insanları gördüğümüzde irkilmeliyiz. İnsanlığımızı kaybetmemek için bunu yapmamız gerekir. 
E.K. de fotoğrafın bu şekilde yayımlanmasının "yıldırı" olduğunu söylemiştir.

Hep terör lafının kullanımıyla ilgili bir sorun olduğunu düşünürüm. Kelime anlamına baktığın zaman yıldırmak anlamına geliyor ya, asıl yıldırı böyle bir şey. Bu bir terör saldırısı olsun ya da olmasın, isterse bir gaz patlaması olsun, tüp patlamış olsun, ama bunun bu şekilde verilmesi asıl yıldırı.

\section{Fotoğraf}

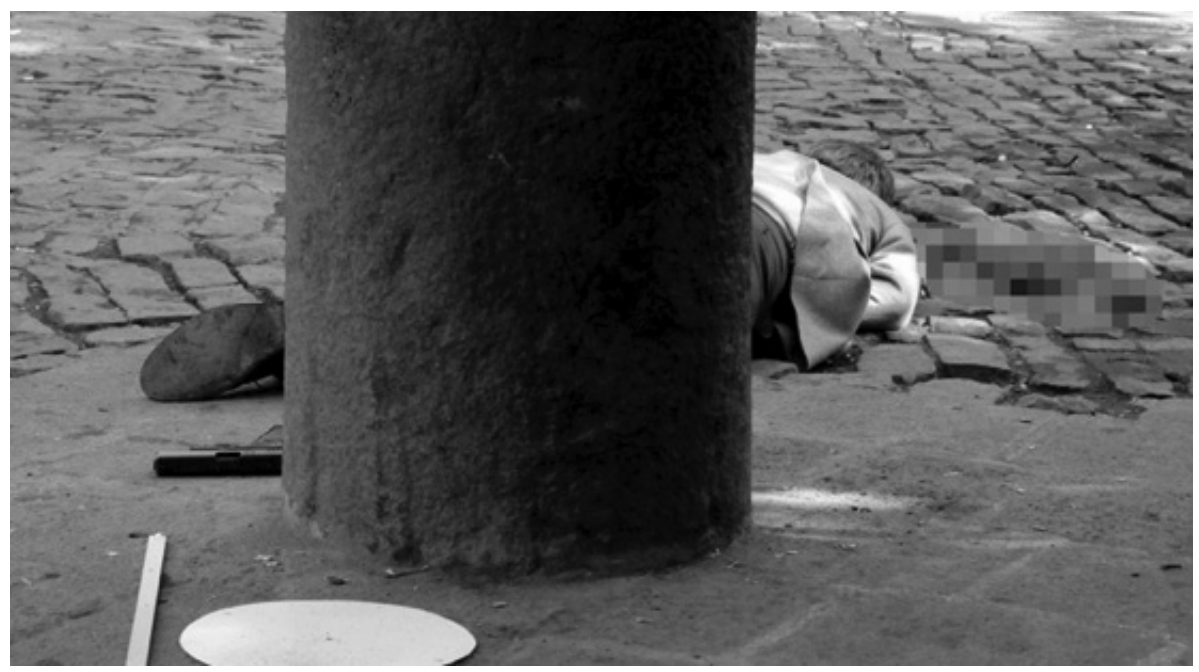

http://www.sozcu.com.tr/2015/gundem/tahir-elcinin-olduruldugu-olayin-detaylari-bellioldu-997505/ (Erișim tarihi: 1 Aralık 2015)

Katılımcılara, silahlı saldırı sonucu hayatını kaybeden Diyarbakır Baro Başkanı Tahir Elçi'nin fotoğrafı da gösterilmiştir. Fotoğraf, katılımcıların yarıya yakınına, 2007 yılında, genel yayın yönetmeni olduğu Agos gazetesinin önünde öldürülen Hrant Dink'i hatırlatmıştır. Katılımcıların büyük bölümü, fotoğrafta bir "çaresizlik" gördüğünü ya da kendini çaresiz hissettiğini ifade etmiştir. Buna karşın, üretilen anlamlar, fotoğraftaki kişinin kim olduğunun katılımcılar tarafından bilinip bilinmemesine bağlı olarak farklılık göstermiştir. Kullandıkları ifadeler, fotoğraftaki kişinin kim olduğunu bilen katılımcıların fotoğraftan daha fazla etkilendiklerini ortaya koymuştur. Bu katılımcılardan biri O.T.'dir.

Tahir Elçi'nin ölü bedeni. Kendisini hiç tanımazdım fakat çok aklı başında bir insan izlenimi vermişti bana. Onun için, bu dört ayaklı minarenin köşesinde ölümünü görmek, Arnavut kaldırımı üzerinde, beni çok rahatsız etmişti. Bu resim tekrar önüme gelince çok kötü oldum. 


\section{B.Ü. çaresizlik ve zayıflık hissettiğini söylemiştir.}

Fotoğrafta bir zayıflık duygusu var. Tahir Elçi'nin zayıflı̆̆ı değil ama bizim aşırı çaresizliğimiz, zayıflığımız. Bu görüntü bende böyle bir şey çağrıştırıyor. Hrant Dink'te de öyle olmuştu. Öldürecekleri belli. Göz göre göre hedef gösteriyorlar, işte plan ve biz de bir şey yapamıyoruz. Kimse önlem almıyor, alamıyor. Böyle bir çaresizlik, böyle bir atalet hissediyorum.

Aynı katılımcı, fotoğrafın kendi tehdit algısını artırdığını da belirtmiştir.

Bazı tehditler aldım geçen sene... O günlerde hissettim, o korkuyu da hissettim. Aklıma geliyordu yani, öyle ensemden gelecekler karanlıkta yürürken falan. Tabii abarttım belki ama dolayısıyla Tahir Elçi'nin şeyini ben daha yakın hissediyorum. O tip bir şey bana da olur mu, ileride olur mu falan gibi.

Fotoğraftaki kişinin kim olduğunu bilmeyen katılımcılar ise, daha çok ideolojik görüşleri ya da kişisel deneyimleri doğrultusunda, fotoğraftaki kişinin mücadele veren bir insan olduğu, yoksul olduğu ya da fotoğrafın Türkiye' nin doğusunda çekilmiş olabileceği gibi yorumlar yapmışlardır.

Hrant Dink'i çağrıştırıyor. Aynı şekilde kaldırımda yatması, ayakkabısının görünmesi, yerdeki kan. Birisi kasıtlı olarak öldürülmüş ve muhakkak bence bir şeyler için mücadele veren bir insanın kim vurduya gitmesi. B.Y.

Belli ki yoksul birisi. Bir şekilde bir kazayla, bir şeyle yok olmuş. İ.U.

Sokaklarda bunları görmeye alıştık. Görüntüler zannedersem doğu tarafında çekilmiştir. Orada ölen insanların aileleri, çocukları... İnsanın, vicdanı olan birinin dayanma şansı yok. Oturup ağladığımız günler oluyor. O çocukların annesi ölüyor, babası ölüyor, başında oturup ağlıyorlar. İster istemez bizim de içimiz kan ağlıyor ama elimizden bir şey gelmiyor... İdarecilerin yapabileceği şeyler var ama ona da bizim müdahale etme şansımız yok. Gider oy veririz seçimlerde, o kadar. Ancak fikrini söylersin "Bunlar doğru değil." diye. Orada ölen; askeri, polisi, sivili, kim olursa olsun hepsi insan. Böyle bakmazsak zaten çözülmez. A.Ö.

G.K. ve E.K. ise, fotoğrafı çeken gazeteciyi eleştirmişlerdir.

Fotoğraf çekmek yerine bir baksaydı. Acaba fotoğrafı çekmeden önce, yaşayıp yaşamadığını kontrol etti mi? Ya yaşıyorsa, hayattaysa, ya yapılacak bir şey varsa. G.K.

Bu çekimle sanki olayı çerçeveliyor ve kendini dışına koyuyor. Oradan, sütunun arkasından röntgencilik yapar gibi çekiyor ama başka bir şey yapmıyor. O kadar yaklaşmak mümkünse o zaman başka bir şey yapmak da mümkün. E.K. 
Katılımcılara, kan görüntüsünün buzlanmış olması hakkındaki düşünceleri de sorulmuştur. Katılımcıların büyük bölümü, fotoğrafa daha rahat bakabildiğini ifade etmiştir. Bazı katılımcılar ise, buzlamaya rağmen rahatsızlık hissettiklerini söylemişlerdir.

\section{Fotoğraf}

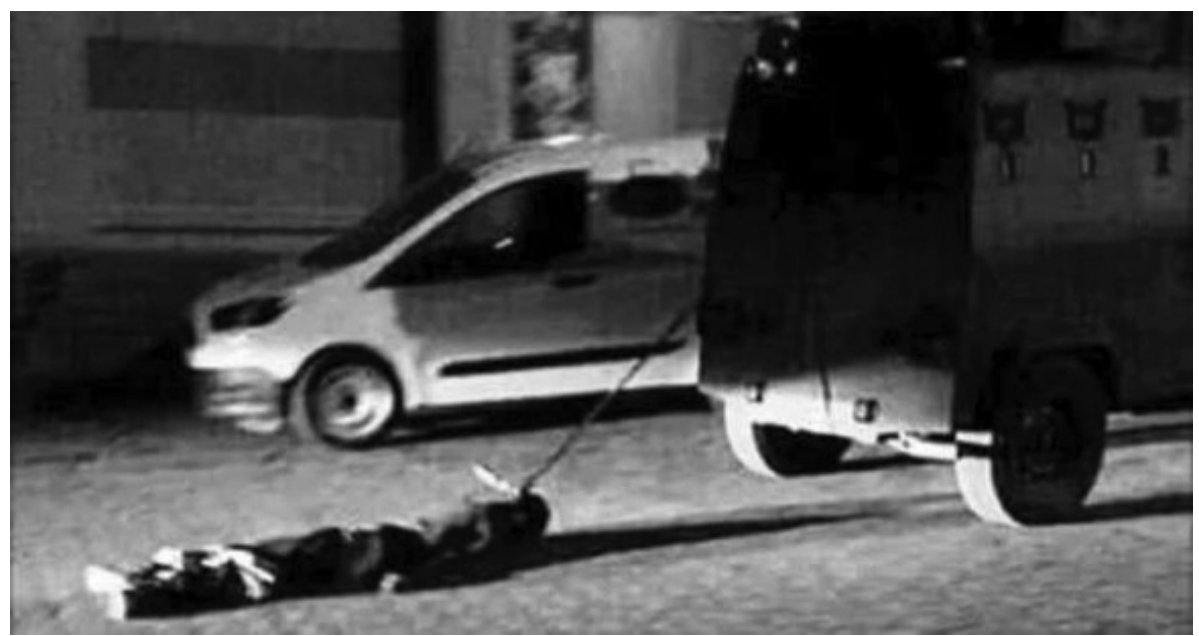

http://www.sabah.com.tr/gundem/2015/12/19/pkkli-cesedini-surukleyen-polisler-meslekten-atildi (Erișim tarihi: 20 Aralık 2015)

Katılımcılara, beşinci olarak, Şırnak'ta güvenlik güçleri ile PKK'nın gençlik yapılanması YDG-H üyeleri arasında yaşanan çatışmada öldükten sonra ölü bedeni zırhlı bir polis aracının arkasına bağlanarak sürüklenen Hacı Lokman Birlik'in fotoğrafı gösterilmiştir. Fotoğrafı bazı katılımcılar dini inançları, bazıları ideolojik görüşleri, bazıları ise kişisel deneyimleri doğrultusunda yorumlamıştır. Buna karşın, katılımcılarda ortak bir hassasiyetin ortaya çıktığı görülmüştür. Katılımcıların neredeyse tamamı, terörist bile olsa, hiç kimseye böyle bir muamelenin yapılmaması gerektiğini ifade etmiştir. Fotoğrafı daha önce görmediğini ve fotoğraftaki kişinin kim olduğunu bilmediğini söyleyen U.D., her koşulda, yapılanı çok yanlış bulduğunu belirtmiştir.

Bu terörist gibi bir şey mi, PKK'lı gibi bir şey mi? Ne olursa olsun herkese saygı duymak gerekiyor. Tamam hani ülke düşmanı gibi bir şeyler, şu anda ülkenin düşmanı sayılıyorlar ama onlar da insan, anneleri babaları var. Bu yapılan çok büyük bir yanlış bence.

M.C. bir insanın bu şekilde sürüklenmesinin üzücü ve ilkel olduğunu söylemiştir. 
İbret-i alem gibi bir şey yapılıyor gibi geldi bana. Her ne ise üzücü... Bir insanı bu şekilde sürüklemek çok ilkel.

B.Ü. ise, amaçlananın aşağılamak olduğunu ve böyle bir muamelenin ancak bir sömürgede yapılabileceğini ifade etmiştir.

Burada amaç çok açık aşağılama. Bunu bir sömürge fotoğrafı olarak görüyorum. Ancak bir sömürgede olur bu. Ülkenin merkezinde, metropolünde, ülkenin kendisinin gördüğü yerlerde böyle bir şey yapamazsın, kimse yapamaz. Gezi'de de mesela, Gezi isyanında da böyle bir şey olmaz. Bu, ancak bir sömürgede olabilir. Sömürgedeki insanları aşağılamak, bir hayvandan aşağı görmek, bunu bütün dünyaya duyurmak, amaçlanan şey o.

A.Ö. insanların bu şekilde yerlerde sürüklenmesinin dini inanışlarına aykırı olduğunu söylemiştir. Aynı katılımcı fotoğrafın yayımlanmasına da tepki göstermiştir.

Bu olay doğru değil. Öldürdüğü, terörist de olsa, yaratılmış insan. Böyle bir şeyin yayınlanmasını hoş karşılamam. Yayınlayanlara çok kızdım; çünkü insanlar bunu seyrediyor ve kutuplaşıyor. Bunu görmese kutuplaşma olmaz. Bunu çocuklar da görüyor. Benim çocuğum da gördü. Bir kızım var, 12 yaşında. Bunu televizyonda gördü ve etkilendi. "Baba" dedi "bunu niye bağlamışlar da çekiyorlar?". Dini yönden de biraz bilgilidir. "Bizim peygamberimiz zamanında dahi böyle şeyler olmadı. İnsanlar taşlandı ama böyle yerlerde sürüklenmedi." dedi. Bizim dini inanışlarımıza aykırı bunlar.

Katılımcılardan sadece H.S. "aracın içindekilerden taraf" olduğunu söylemiştir. H.S.'nin anlam üretiminde kişisel deneyimi etkili olmuştur.

Bir taraftan ilkesel doğrular var. İlkesel doğruların kabul edilmesi, uygulanması çok önemli; fakat bu doğrular genellikle ideal şartlarda geçerlidir. Daha dün bizim acil hemşirelerinden birinin eşi şehit oldu burada. Dolayısıyla ben bu konuda tarafım. Aracın içindekilerden tarafım... Ölü beden canlıdan daha değerli değil... Bu kişi canlı olsaydı, o zaman kabul edilemez bir şey olurdu; o, işkenceye girerdi. Burada ayrı bir şey daha var. Bunların öncesini de görmek lazım. Yani bu kişi kime ateş etti, ateş etti mi etmedi mi? Bu kişi yoldan geçen biri ise, bu hiç kabul edilebilecek bir şey değil ama bu kişi bir saat önce bu aracın içindeki kişilere ateş etmiş ise, o zaman onların ruh haline, buradan oturup "Çok ahlaksızca bir şey yapmışlar" deme lüksüne sahip olduğumu hissetmiyorum ben. 
6. Fotoğraf

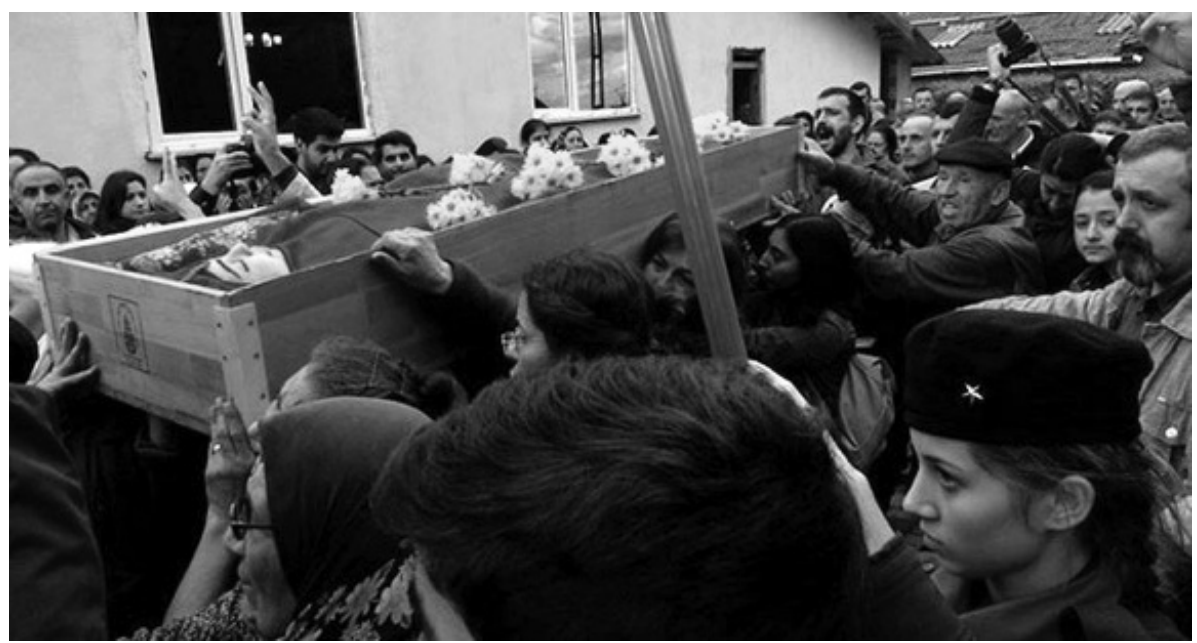

http://www.taraf.com.tr/dilek-dogan-son-yolculuguna-ugurlaniyor/

(Erișim tarihi: 1 Kasım 2015)

Katılımcılara son olarak, bir terör operasyonu çerçevesinde İstanbul' daki evinde arama yapılırken polis silahından çıkan kurşunla ağır yaralanan ve tedavi gördüğü hastanede hayatını kaybeden Dilek Doğan'ın cenaze töreninden bir fotoğraf gösterilmiştir. Katılımcılar fotoğrafı ilk kez gördüklerini ve fotoğraftaki kişinin kim olduğunu bilmediklerini söylemişlerdir. Bu bilgi olmaksızın yapılan yorumlarda, ölen kişinin yüzünün açık olmasına odaklanılmıştır. Katılımcıların yarısı bundan rahatsızlık duyduğunu, diğer yarısı duymadığını ifade etmiştir. Katılımcıların yarıya yakınının anlam üretiminde dini inançlarının etkili olduğu görülmüştür. Bu katılımcılar farklı cinsiyet, yaş ve eğitim düzeylerindendir.

A.Ö. hem fotoğraftaki kişinin yüzünün açık olmasını hem de bir kadının ölü bedeninin erkekler tarafından görülmesini uygun bulmadığını ifade etmiştir.

Bizim dini inanışlarımıza göre, kefenlenmiş birisinin hiçbir tarafı görünmez. Yanlış. Tabutun üstü açık olmaz. Yanlış. Müslümanlıkta böyle bir şey yok. Yıkanır, kefenlenir, cenazesi tabuta konulur, mezarlığa götürülür, mezarlıkta çıkarılır ve direkt defnedilir. Bayan cenazesini erkeğin görmesi uygun değil. Taşıyanlar da erkek. Uygun olmayan bir durum yani. Ters.

G.K. de dini inançları doğrultusunda anlam üretmiştir. 
Yüzün açık olması rahatsızlık veriyor. Bizim dini değerlerimizle, toplumsal değerlerimizle örtüşen bir şey değil. Hristiyan filmlerinde makyaj yapılmış bedenler görmeye alışığız ama o hep filmde olan bir şeydi... Bence yüzü kapalı olmalıydı, hatta tabut tamamen kapalı olmalıydı. Ölen kişi hiçbir zaman bu şekilde teşhir edilmemeli. Onun ruhunu incittiğini düşünüyorum. Oradaki herkesi suçluyorum şu anda. Hepsinin bu suça ortak olduğunu düşünüyorum.

U.D. de fotoğrafa dini inançlarını temel alarak yaklaşmıştır. U.D. ölen kişinin yüzünün açık olmasını sıradışı bulduğunu, fakat bunun kendisini rahatsız etmediğini söylemiştir.

Burada beni çok fazla rahatsız eden bir şey yok ama bizde açıklık merasimi diye bir şey yok. Normalde açılmaması gerekiyor yani. Çok görmek isteyen olursa, 'Son kez göreyim' diyen olursa belki açılabilir. Ben birkaç cenazede denk gelmiştim öyle. Açıp hemen kapatıyorlar, ama bu sıradışı bir şey olmuş.

Fotoğraftaki kişinin kim olduğunu soran katılımcılara, bu kişinin Dilek Doğan olduğu söylenmiştir. Katılımcılar bu bilgiyi aldıktan sonra, Doğan'ın öldürülmesine, Alevi kültürüne ve Alevilerin yaşadıkları sorunlara ilişkin anlam üretmişlerdir.

Polis tarafından öldürüldüğü iyice anlaşıldı artık. Tabuta konulmuş. Yüzü açık. Galiba cemevine götürülürken ya da oradan çıkarılıken çekilmiş fotoğrafı; çünkü Alevi bir ailenin kızı. Çok genç yaşta bir insan, 19 yaşında galiba. Onun öldürülmesi çok kötü olmuş. Hayatının baharında olan genç bir kızın çiçeklerle uğurlanması beni çok rahatsız etti. O.T.

Daha önce fotoğraftaki kişinin yüzünün açık olmasının kendisini rahatsız ettiğini söyleyen G.K., Alevi kültüründe de böyle bir uygulamanın olmadığı yorumunu yapmıştır.

Alevi kültürünü biliyorum. Alevi kültüründe böyle bir şey yok. Bu başka bir akım, bir örgütün başlattığı eylemin devamı. Başka bir amaçla bunu yapıyorlar. Bağlı oldukları bir illegal örgütün tavrı bu.

Kendisinin Sünni olduğunu belirten H.S. ise, Aleviliğin nasıl olduğuna Alevilerin kendilerinin karar vermeleri gerektiğini söylemiştir.

Yüzün açık olması beni hiç rahatsız etmiyor. Bu tamamen bireysel bir tercihtir, kendi tasarruflarıdır. Nasıl istiyorlarsa o şekilde yaparlar ve diğerlerinin de buna saygı göstermesi gerekir. Ben Sünniyim fakat Alevilere karşı pozitif ayrımcılık yapılması gerektiğine inanan biriyim ve bunu hayatımda uygulamaya çalışıyorum. Sünniler'in hakikaten "Alevilik öyle, Alevilik böyle" demeyi birakmaları 
gerektiğine inanıyorum. Kendileri nasıl hissediyorsa, nasıl algılıyorsa; mezhep midir, tarikat mıdır, başka bir şey midir kendileri karar vermeli. Bir de üzülüyorum, çünkü gerçekten bu ülkenin sosyo-ekonomik gelişmişliklerinden en az payı alan gruplardan biridir Aleviler. Aynı zamanda Kürt olmayanlarının sesi de çok fazla çıkmamaktadır.

B.Ü. de daha önce edinmiş olduğu bilgiler doğrultusunda, çok mazlum bir halk gördüğünü söylemiştir.

Bu bir Alevi cemaati. Bu kız da, kafasında herhalde bir tür gerilla şeyi var, onu çağrıştırıyor, bir militan şapkasını çağrıştırıyor. Çok mazlum bir halk görüyorum ben burada. Neredeyse ırka dair, Afrika'daki ırkçılığa benzer bir mazlumluk, siyahlarınkine benzer yani. Bir yandan çok mazlum bir halk, çok acı çekmiş, bir yandan bir direniş şeyi de var.

\section{Fotoğraflara Toplu Bakıș}

Katılımcılara, fotoğrafları yorumlarken zaman zaman değinmiş olsalar da, fotoğrafların tümü gösterildikten sonra, bunlar ışığında, haberlerde ölü beden fotoğraflarının kullanılması konusunda ne düşündükleri sorulmuştur. Katılımcıların bir bölümü, ölü beden fotoğraflarının yayımlanmasına karşı olduğunu ifade etmiştir. A.Ö. gerekçe olarak, herkesin fotoğraflardan etkilenmesini göstermiştir.

Bunları çekenler görevlerini yapıyor olabilir ama yayınlarken biraz düşünseler bunları yayınlamazlar. Herkes etkileniyor.

U.D. fotoğrafların özellikle çocukları olumsuz etkilendiğini söylemiştir.

Tepkiliyim. Görmek istemiyorum. Bunları gören çocukların da psikolojisi bozulur.

G.K. ölü beden fotoğraflarının yayımlanmasına, "insanları ölüme ve şiddete alıştırdığı için” karşı olduğunu kaydetmiştir. G.K. fotoğrafları mahremiyet ihlali olarak gördüğünü belirtmiştir.

Haberlerde ölmüş insanların gösterilmesini çok kötü karşılıyorum. Gösterilmemesi gerektiğini düşünüyorum. İnsanların bir şekilde ölüme alıştığını, alıştırıldığını düşünüyorum. Sürekli ölü bedenler görüyoruz ve bu bizim için normalleşiyor. Şiddeti kanıksadık, ölüme üzülmekten vazgeçer olduk; bu üzücü bir durum... Bedenin mahremiyetini korumak gerek diye düşünüyorum.

M.C. de mahremiyete vurgu yapmıştır. 
Bu fotoğrafların kullanılmaması lazım. Bazı şeyler mahrem kalmalı. Bilgi olarak verilebilir, göstermeden, daha değişik şekillerde anlatılabilir. Herkes bu fotoğraflara iyi niyetle de bakmıyor. Kimi insanlar başkalarının üzüntülerine seviniyorlar. Ben kendimin ya da yakınlarımın böyle bir fotoğrafının kullanılmasını kesinlikle arzu etmem.

Katılımcıların bir bölümü ise, ölü beden fotoğraflarının yayımlanabileceğini, ancak bunun sınırları olması gerektiğini dile getirmiştir. Bu katılımcıların eğitim düzeylerinin, ilk gruptaki katılımcılardan daha yüksek olduğu tespit edilmiştir. B.Y. ölü beden fotoğraflarının, "saklanmaya çalışılan şeylerin bir belgesi" olduğu yorumunu yapmıştır. Ancak, ölen kişilerin yüzlerinin gösterilmemesi gerektiğini belirtmiştir.

Ben, fotoğrafçıların işlerini yaptıklarını düşünüyorum. Bu fotoğrafları büyük bir acı içinde çektiklerini düşünüyorum. Bu tarz görüntüler, saklanmaya çalışılan şeylerin aslında bir belgesi. O yüzden, bence belli ölçülerde kullanılabilir. Fakat, yüzün kapatılması gerekir; çünkü kimseyi böyle görmek istemeyiz. O kişinin ailesi de, onu hep iyi haliyle, mutlu haliyle hatırlamak ister.

İ.U. ölü beden fotoğraflarının yayımlanmasının "olumsuz tabloların tekrar ortaya çıkmamasına" katkıda bulunabileceğini söylemiştir. Bununla birlikte; bütünlüğü bozulmuş beden, "fazla kan" ve ölen kişinin yüzünün gösterilmemesi gerektiğini belirtmiştir.

Bence ölmüş insanların görüntüleri haberlerde kullanılabilir. Öldüğüm zaman benim görüntülerimi de kullanabilirler. Şu görüntüleri görmemiz, görmememizden daha iyi diye düşünüyorum. Belki birtakım insanlar bu olumsuz tabloların tekrar ortaya çıkmaması için elbirliği ederler. Fakat, tabii, parçalanmış cesetlerin, ölen kişilerin suratlarının gösterilmemesi gerekiyor bence. Fazla kan da gösterilmemeli.

O.T. etik kurallara dikkat çekmiş ve "insanları en az rahatsız edecek" fotoğrafların seçilmesi gerektiğini söylemiştir.

Gazeteciler, fotoğrafçılar görevlerini yapıyorlar. Günümüz dünyasında maalesef bazı şeylerin haber içinde gösterilmesi gerekmektedir. Fakat bunun çok iyi bir şekilde, yani etik kurallar düşünülerek yapılması gerekir. Mümkün olduğu kadar, insanları en az rahatsız edecek olan görüntüler seçilmeli ve kullanılmalıdır.

H.S. fotoğrafların "bir faydaya karşılık gelecek ise” yayımlanabileceğini ifade etmiştir. 
Ben bu görüntülerin olması gerektiğine inananlardanım. Bir kişi, kendi ölümünün resmedilmesine, bunun yayınlanmasına ne diyebilir; bu hakikaten bireysel tercihlere girebilecek bir konu. Ama şahsım adına, bunu herhalde fayda açısından değerlendirmek lazım diye düşünüyorum. Eğer bir takım duyarlılıkların artması için bir faydaya karşılık gelecek ise kendi görüntümün yayımlanmasını da uygun bulurum.

H.S. buna karşın, “teknik olarak sorunsuz görünen fotoğrafların” bile olumsuz etkilerinin olabileceğini belirtmiştir.

Bizde, karşımızdaki durumu veya şeyi taklit etmemizi sağlayan bir takım nöronlar var, ayna nöronlar. Bunlar görsel olarak çalışıyor. Karşınızdaki su içiyorsa sizde su içme ya da sigara içiyorsa sigara içme etkisi oluşturabiliyor. Aynı zamanda, öğrenmenin de en önemli yollarından biri bu. Özellikle çocuklarda, bu çok daha belirgin. Dolayısıyla, teknik olarak sorunsuz görünen bir takım fotoğrafların bile çok farklı bir şey içine sokabileceği zaman içinde ortaya çıkabilir.

E.K. görüş oluşturmakta zorlandığını aktarmıştır.

Bu görüntülere baktığımda, ağzımdan "gösterilmemeli" çıkıyor; ama bir yandan da aklıma Tahir Elçi geliyor, Hrant Dink geliyor. Onun orada öyle yattığını bilmem gerekir diye düşünüyorum. Bunu nasıl ayırt edeceğimi kestiremiyorum.

B.Ü. ise, kamusal yararın mı yoksa özel yararın mı tercih edilmesi gerektiğinden emin olamadığını söylemiştir.

Bizde sanki kamusal özelden daha önemli gibi bir şey var. Yani kamusal yarar olacaksa özele tercih edilmeli diye, ama bir yandan da emin olamıyorum. Çünkü yaşadığımız dünya belli. "Kamusal” deyip deyip hiçbir şey düzelmiyor, bir sürü şey kötüye gidiyor. Dolayısıyla, belki de en azından insanların mahremini korumak iyi olabilir diye düşünüyorum bazen. Hiç değilse o aileyi korumak, o ailenin bir şekilde daha kötü hissetmemesini, perişan olmamasını sağlamak biraz daha akıllıca olabilir.

\section{Sonuç ve Değerlendirme}

Bu çalışmada, haberlerde kullanılan ölü beden fotoğraflarının okurlar tarafından nasıl alımlandığı, farklı sosyo-demografik özelliklere sahip 10 kişi ile altı haber fotoğrafı üzerine derinlemesine görüşmeler yapılarak incelenmiştir.

Görüşmeler, çalışmanın başında varsayıldığı gibi, katılımcıların fotoğraflar karşısında aktif konumda bulunduklarını ve aynı fotoğraflara ilişkin çoğu kez farklı anlamlar ürettiklerini göstermiştir. Katılımcılar fotoğrafları ağırlıklı 
olarak; kişisel deneyimleri, ideolojik görüşleri ya da dini inançları doğrultusunda anlamlandırmışlardır. Katılımcıların cinsiyetlerinin, yaşlarının, eğitim düzeylerinin ve mesleklerinin de fotoğrafları alımlama biçimlerini etkilediği tespit edilmiştir. Katılımcıların fotoğraftaki kişi ve ölüm nedeni hakkında bilgi sahibi olup olmamaları, ölü beden ve kan görüntüsüyle ne sıklıkta karşılaştıkları ve fotoğrafın çekildiği yerden ne kadar uzakta bulundukları da anlam üretimlerini farklılaştırmıştır. Buna karşın, bazı ortak anlamlar da üretilmiş ve etik sınırlar çizilmiştir.

Katılımcılar, çoğu zaman, kendilerini ölen kişiler ve yakınları ile özdeşleştirerek acı ve çaresizlik hissettiklerini ifade etmişlerdir. Özdeşleşmenin gerçekleştiği noktada, fotoğraflar, mahremiyet hakkının ihlali olarak değerlendirilmiştir. Katılımcıların büyük bölümü, fotoğrafların neden çekildiğini sorgulamış ve gazetecilerden insani yaklaşım beklediğini ifade etmiştir. Gazetecilerin fotoğraf çekmek yerine, fotoğrafını çektikleri kişinin yaşayıp yaşamadığını kontrol etmesi, yaşıyor ise bu kişiye yardım etmeye çalışması gerektiği yönündeki düşünceler dile getirilmiştir.

Ölü bedeni zırhlı bir polis aracının arkasına bağlanarak sürüklenen Hacı Lokman Birlik'in fotoğrafında, ölen kişinin kim olduğu fark yaratmaksızın, ölü bedene yapılan muameleye ilişkin ortak bir hassasiyet ortaya konulmuştur. Bazı katılımcılar fotoğrafı dini inançları, bazıları ideolojik görüşleri, bazıları ise kişisel deneyimleri doğrultusunda anlamlandırmıştır. Farklı dayanak noktaları bulunsa da, katılımcıların neredeyse tamamı, hiç kimseye böyle bir muamelenin yapılmaması gerektiğini kaydetmiştir.

Çalışma, genel kabulün aksine, okurların ölü beden fotoğraflarını görmeye istekli olduklarını iddia etmenin güç olduğunu ortaya koymaktadır. Katılımcıların bir bölümü, ölü beden fotoğraflarıyla kesinlikle karşılaşmak istemediğini ve bu fotoğrafların yayımlanmasına karşı olduğunu söylemiştir. Bu yaklaşımlarının nedenleri; kendi ifadeleri ile "mahremiyetin ihlal ediliyor olması", "ölü beden fotoğraflarının insanları ölüme ve şiddete alıştırması" ve "özellikle çocukların bu fotoğraflardan olumsuz etkilenmesi"dir. Bazı katılımcılar ise, ölü beden fotoğraflarının, bir fayda elde edilecek ise yayımlanabileceğini ancak bunun mutlaka sınırları olması gerektiğini belirtmişlerdir.

Ölü beden fotoğraflarının belirli sınırlar dâhilinde yayımlanabileceği görüşündeki katılımcılardan bazıları, bütünlüğü bozulmuş bedenlerin ve ölen kişinin yüzünün gösterilmemesi gerektiğini söylemişlerdir. Bazı katılımcılar ise, "fazla kan" görmek istemediklerini aktarmışlardır. İnsanları en az rahatsız 
edecek görüntülerin seçilerek kullanılması gerektiği görüşü de ifade edilmiştir. Katılımcıların fotoğraflara ilişkin ürettikleri anlamlar, böyle bir seçimde, her fotoğraf için ayrı bir değerlendirme yapılması gerektiğini göstermektedir. Ölü bedenleri yakın plan gösteren fotoğrafların genellikle daha çarpıcı ve rahatsız edici oldukları düşünülür. Buna karşın, çalışmada, terör saldırılarının ardından çekilmiş olan iki fotoğraftan, toplu ölümleri genel plan gösteren fotoğrafın, yakın plan fotoğraftan daha rahatsız edici bulunduğu belirlenmiştir. Hatta katılımcıların yarıya yakını, fotoğrafa bakmak ve fotoğrafın "çok korkunç" olduğunu ya da kendisine rahatsızlık verdiğini söylemenin ötesinde anlam üretmek istememiştir.

Katılımcıların, ilk anda çok rahatsız edici buldukları fotoğraflara bakmayı ve bu fotoğraflara ilişkin kapsamlı anlam üretmeyi reddetmiş olmaları önemlidir. Bu bulgu, hangi gerekçe ile yayımlanıyor olursa olsun, fotoğraflar ile amaca ulaşabilmek için, okurların hassasiyetlerinin dikkate alınmasının zorunlu olduğunu göstermektedir. Çalışmanın, bu bulgudan da hareketle, çoğu zaman hem ölen kişinin mahremiyetini ve onurunu zedeleyen hem de yakınlarının yaşadığı travmayı artıran ölü beden fotoğraflarının haberlerde kullanımı konusunda yeni bir tavrın gelişmesine katkıda bulunması ve bu konuda bundan sonra yapılacak çalışmalar için bir başlangıç noktası oluşturması umulmaktadır. ${ }^{37}$ 


\section{Notlar}

1 Türk Dil Kurumu, Büyük Türkçe Sözlük, erişim tarihi: 11 Aralık 2015, http:/ / tdk.gov.tr / index.php?option=com_bts\&arama=kelime\&guid=TDK. GTS.57a49d75d5cc01.94715835

2 Martin Heidegger, Being and Time, çev. John Macquarrie, Edward Robinson (Oxford: Blackwell, 2001), 307.

3 Norbert Elias, The Loneliness of the Dying, çev. Edmund Jephcott (New York: Continuum, 2001), 18-23.

4 Guy Debord, La Société du Spectacle (Paris: Editions Gallimard, 1992), 10-26.

5 Nilgün Tutal, “Televizyon: Patolojik ve Sağaltıcı Kamusal Alan ve Ötekinin Acısı ve Yasının İmkânsız Kılınması," Azınlıklar, Ötekiler ve Medya içinde, der. Yasemin İnceoğlu ve Savaş Çoban (İstanbul: Ayrınt1, 2014), 287;

Susan Sontag, Başkalarının Acısına Bakmak, çev. Osman Akınhay (İstanbul: Agora Kitaplığı, 2004), 17- 18.

6 "Aylan bebek" olarak tanınan üç yaşındaki Suriyeli Alan Kurdi'nin ölü bedeninin fotoğrafını yayımlayan Fransız Le Monde gazetesinin genel yayın yönetmeni Jérôme Fenoglio, "Mülteciler: Gözleri Açmak İçin Bir Fotoğraf" başlıklı yazısında, tek arzularının, "anın gerçekliğinin bir parçasını yakalamak" olduğunu belirtmiştir.

Erişim tarihi: 12 Aralık 2015, http:/ / www.lemonde.fr/ europe/article/ 2015/09/03/ouvrirles-yeux_4744650_3214.html

Hürriyet gazetesi de, fotoğrafı, “dünyanın gözünü kapattığı mülteci dramına dikkat çekmek için" yayımladığını duyurmuştur.

Erişim tarihi: 12 Aralık 2015, http:/ / www.hurriyet.com.tr/ dunyayi-sarsan-o-fotografgazetelerin-mansetlerinde-29975363

7 Hüseyin Köse ve Bahar Balcı, “Sapkın Vizör: Medyada Ölümün ve Ölü Bedenlerin Görsel Temsili ve Suriye İç Savaşı Örneği," Galatasaray Üniversitesi İletişim Dergisi 24 (2016): 55-78.

8 Tal Morse, “Covering the Dead," Journalism Studies 15 (1) (2014): 98-113.

9 Refia Palabıyıkoğlu, “Medya ve Şiddet,” Kriz Dergisi 5 (2) (1997): 124-125.

10 Şahinde Yavuz, "Kitle İletişim Araştırmalarında Anadamar/Çoğulcu ve Eleştirel/Radikal Kuram Arasında Yöndeşme Tartışmaları," Karadeniz Teknik Üniversitesi İletişim Araştırmaları Dergisi, 1 (9) (2015), 33.

11 Klaus Bruhn Jensen ve Karl Erik Rosengren, “İzleyicinin Peşindeki Beş Gelenek," Medya ve İzleyici içinde, çev. Şahinde Yavuz ve Yiğit Yavuz, der. Şahinde Yavuz (Ankara: Vadi, 2005), 63.

12 Mehmet Yüksel, "Mahremiyet Hakkı ve Sosyo-Tarihsel Gelişimi," Ankara Üniversitesi Siyasal Bilgiler Fakültesi Dergisi 58 (1) (2003): 182-187.

13 Von Hannover/Almanya (No.2), 7 Şubat 2012 tarihli Büyük Daire kararı, §96, erişim tarihi: 14 Aralık 2015, http:/ / hudoc.echr.coe.int/eng?i\%3D001-109029\#\{“itemid”:[“001-109029”]\} 
14 “Avrupa İnsan Hakları Sözleşmesi," erişim tarihi: 14 Aralık 2015, http:/ / www.echr.coe.int/ documents/convention_tur.pdf

15 Ruşen Keleş, "Kıyıların Korunması ve Toplum Yararı," Ankara Üniversitesi Siyasal Bilgiler Fakültesi Dergisi 44 (1- 2) (1989): 57-58.

16 Ümit Gezder, “Ölüm Sonrası Hatırayı Koruma Doktrini ve Ölüm Sonrası Kişiliğin Korunması Teorisi," İstanbul Üniversitesi Hukuk Fakültesi Mecmuası 65 (1) (2007): 207-213.

17 Cour Européenne des Droits de l'Homme, “Communiqué du Greffier”, erişim tarihi: 14 Aralık 2015, https:/ / wcd.coe.int / ViewDoc.jsp?id=1150595\&Site=COE\#

18 Korkmaz Alemdar, Medya Gücü ve Demokratik Kurumlar (İstanbul: Afa, 1999), 253.

19 “Basın Meslek İlkeleri,” erişim tarihi: 11 Aralık 2015, http:/ / basinkonseyi.org.tr / basinmeslek-ilkeleri/

20 “Türkiye Gazetecilik Hak ve Sorumluluk Bildirgesi," erişim tarihi: 11 Aralık 2015, http:/ / www.tgc.org.tr/bildirgeler/turkiye-gazetecilik-hak-ve-sorumluluk-bildirgesi.html

21 “Yazılı Basın Yayın İlkeleri,” erişim tarihi: 11 Aralık 2015, http:/ / www.doganholding.com.tr/_files/pdf/yayin_ilkeleri_yazili_basin.pdf

22 Bunun bir örneği; 2 Ocak 2014 tarihinde Hürriyet Gazetesi'nin Ege ekinin ilk sayfasında yayımlanan, intihar etmiş bir genç kızın yakın plan çekilmiş kanlar içindeki fotoğrafıdır.

23 Denis McQuail ve Sven Windahl, Communication Models for the Study of Mass Communication (NY: Routledge, 1993), 132-133.

24 Jensen ve Rosengren, "İzleyicinin," 58.

25 Jensen ve Rosengren, “İzleyicinin,” 65.

26 Graham Murdock, "Cultural Studies: Missing Links," Critical Studies in Mass Communication 6 (4) (1989): 436.

27 Stuart Hall, “Encoding/ Decoding," Culture, Media, Language içinde, der. Dorothy Hobson, Andrew Lowe ve Paul Willis (Londra: Hutchinson, 1980), 128-138.

28 Hall, “Encoding,” 136-137.

29 Ian Angus, vd., "Reflections upon the Encoding/ Decoding Model: An Interview with Stuart Hall," Viewing, Reading, Listening: Audiences and Cultural Reception içinde, der. Jon Cruz ve Justin Lewis (Boulder: Westview, 1993), 265.

30 Pasquier Dominique, "Introduction," Sociologie de la Communication, 1 (1) (1997): 735-737.

31 Yavuz, "Kitle," 33.

32 Graeme Turner, İngiliz Kültürel Çalışmaları, çev. Deniz Özçetin ve Burak Özçetin (Ankara: Heretik, 2016), 158- 161.

33 Elihu Katz ve Tamar Liebes, "Interacting With 'Dallas': Cross Cultural Readings of American TV," Canadian Journal of Communication, 15 (1) (1990): 45-66. 
$90<$ ilef dergisi

34 Klaus Bruhn Jensen, “Sosyal Kaynak Olarak Haberler: Danimarka Televizyon Haberleri Hakkında Nitel Ampirik Bir Çalışma," Medya ve İzleyici içinde, çev. ve der. Şahinde Yavuz (Ankara: Vadi, 2005), 155-156.

35 Oya Şakı Aydın, "Alımlama Araştırmaları ve Kültürel Çalışmalar Geleneğinin Katkısı," İstanbul Ticaret Üniversitesi Sosyal Bilimler Dergisi, 6 (11) (2007): 129.

36 Brigitta Hoijer, “İzleyicilerin Televizyon Programlarını Alımlayışı: Kuramsal ve Metodolojik Değerlendirmeler," Medya ve İzleyici içinde, çev. ve der. Şahinde Yavuz (Ankara: Vadi, 2005), 110-111.

37 Prof. Dr. Çiler Dursun'a, Prof. Dr. Nur Betül Çelik'e ve bu makalenin hakemlerine önerileri ve yapıcı eleştirileri için teşekkür ederim. 